\title{
Peningkatan Kesehatan dan Kesejahteraan Masyarakat Melalui Pendampingan Perencanaan Apresiatif Desa Di Desa Benelan Kidul Kecamatan Singojuruh Kabupaten Banyuwangi
}

\author{
Muhamad Annas' ${ }^{1}$, Sumari Mawardi' ${ }^{2}$ Munawir $^{3}$ \\ 1,3 Fakultas Ekonomi dan Bisnis Islam, ${ }^{2}$ Fakultas Tarbiyah dan Keguruan \\ IAI Darussalam Blokagung Banyuwangi \\ Email: ${ }^{1}$ muhamadannas127.iaida@gmail.com, ${ }^{3}$ munawiriaida@gmail.com
}

\begin{abstract}
This dedication was carried out to improve the health and welfare of the community through the assistance of Village Appreciative Planning in Benelan Kidul Village, Singojuruh Subdistrict, Banyuwangi Regency. The results of community service show that the community realizes that the problem of waste must be handled together with all elements of the community. Clean and healthy living is the desire of all citizens. Household Waste Sorting is based on the results of the Healthy Lifestyle Training that has been carried out in each hamlet with PKK cadre participants and study group mothers. The transportation system from households is temporarily collected in a sorting place located in each hamlet, where the selection points are determined by the hamlet head. Waste sorting is carried out in temporary sorting sites located in each hamlet by sorting out Organic and Inorganic waste. Where for organic waste is managed into fertilizer while inorganic waste, especially plastic waste will be managed into plastic ore. Garbage Bank is a business unit that is under the coordination of BUMDes so that marketing of organic and inorganic waste sorting results will be coordinated through BUMDes.
\end{abstract}

Keywords: Empowerment, Health, Well-being, BUMDes

\section{Pendahuluan}

Perkumpulan Pemberdayaan Masyarakat Paradigma telah menjalin kerja sama dengan PT Tirta Investama, Tbk. Yang memproduksi air minum dalam kemasan (AMDK) dengan merk Aqua, dalam program pengembangan kapasitas masyarakat yang berjudul "Peningkatan Kesehatan dan Kesejahteraan Masyarakat Desa Benelan Kidul”, di Kecamatan Singojuruh, Kabupaten Banyuwangi sejak November 2019 hingga akhir April 2020. Desa 
Benelan Kidul Memiliki 6 dusun antara lain : Dusun Gombol, Dusun Cawang, Dusun Suko, Dusun Gebang, Dusun Padang Bulan dan Dusun Tabanan. Adapun hasil yang ingin dicapai dari pelaksanaan program pendampingan tersebut adalah membaiknya pemahaman masyarakat dan pemerintah desa dalam perilaku hidup sehat dan sejahtera melalui proses pembangunan desa yang inklusif dan partisipatif. Dari pernyataan tersebut setidaknya ada dua keluaran kunci yang dapat dipergunakan untuk melihat keberhasilan program, yakni pembangunan desa dan perilaku masyarakat untuk hidup sehat sejahtera.

Asumsi perubahan di atas didasarkan pada beberapa isu yang muncul di masyarakat Benelan Kidul, seperti rendahnya pengetahuan masyarakat dalam perilaku hidup sehat dan bersih. Gejala yang muncul yakni masyarakat masih membuang sampah di sembarang tempat, seperti di sungai dan lahan atau tempat yang menurut warga kurang dimanfaatkan. Masyarakat juga masih banyak yang buang air besar di sungai karena tidak memiliki jamban sendiri di rumahnya. Sementara itu, kesedaran kesehatan reproduksi juga masih rendah seiring dengan masih beroperasinya-meski sembunyisembunyi-lokalisasi pekerja seks komersial di Dusun Padang Bulan, Desa Benelan Kidul. Problem lainnya yakni minimnya infrastruktur fisik di desa Benelan Kidul yang dapat mendukung masyarakatnya agar senantiasa berperilaku hidup sehat dan bersih.

Seiring dengan dengan transformasi hukum dan kebijakan di Indonesia mengenai desa, maka konteks desa tidak hanya dipandang sebagai pemerintah desa saja. Desa saat ini adalah entitas masyarakat berpemerintahan yang menyatu secara kultur dan hukum dalam menjalankan dan mengatur pembangunan desa. Untuk itu, setiap inisiatif perubahan ke arah kesejahteraan dan kemandirian desa ditentukan pula oleh masyarakat desa itu sendiri. Masyarakat boleh menentukan model dan pola desa yang dikehendakinya, termasuk salah satunya bagaimana masyarakat 
berperilaku hidup sehat dan bersih melalui pelaksanaan pembangunan desa yang partisipatif dan inklusif.

Inisiatif yang dikembangkan oleh Perkumpulan Pemberdayaan Masyarakat Paradigma dan PT. Tirta Investama, Tbk. Yang memproduksi air minum dalam kemasan (AMDK) dengan merk Aqua hendak mencapai perubahan masyarakat Desa Benelan Kidul atas isu-isu yang muncul di masyarakat. Berdasarkan ulasan singkat atas desain program pendampingan, pernyataan perubahan yang dimaksud adalah "Jika masyarakat Desa Benelan Kidul memiliki kapasitas untuk berperilaku hidup sehat dan bersih serta mengembangkan aset dan potensi desa ke arah masyarakat yang sehat dan sejahtera, maka masyarakat desa Benelan Kidul akan hidup sehat, mandiri dan sejahtera karena tersedianya dukungan dari pemerintah desa dan pihak lain secara berkesinambungan.

Berdasarkan latar belakang di atas, muncul pertanyaan kritis dari proses yang dijalankan oleh Perkumpulan Pemberdayaan Masyarakat Paradigma dan PT. Tirta Investama, Tbk. Yang memproduksi air minum dalam kemasan (AMDK) dengan merk Aqua. Pertama, bagaimana proses transformasi sosial ke arah hidup sehat dan bersih yang dijalankan? Kedua, apa saja faktor-faktor penunjang yang dapat mendukung pelaksanaan inisiatif tersebut? Untuk itu, tujuan dari pemberdayaan masyarakat ini adalah pertama mengetahui pembelajaran dan manfaat yang dihasilkan atas inisiatif ini. Kedua, memetakan aktor yang dapat mendukung dan menghambat proses perubahan sosial. Ketiga, mengidentifikasi isu-isu strategis yang dapat dikembangkan dan diterapkan di masyarakat pada masa mendatang untuk kemajuan dan kemandirian pada aspek ekonomi, sosial dan lingkungan.

Perencanaan Apresiatif Desa adalah Inisiatif yang merupakan upaya untuk menyusun perencanaan desa secara partisipatif. Masyarakat dilibatkan dalam penyusunan perencanaan desa. Keluaran dari Perencanaan Apresiatif Desa adalah data dan dokumen tentang kesejahteraan desa, potensi desa, 
kewenangan desa, peta kelompok marjinal di desa dan rekomendasi perbaikan pelayanan di desa. Pelbagai data tersebut akan menjadi bahan dalam penyusunan penjabaran visi, misi dan strategi pembangunan yang tertuang dalam dokumen Rencana Pembangunan Jangka Menengah Desa (RPJM Desa).

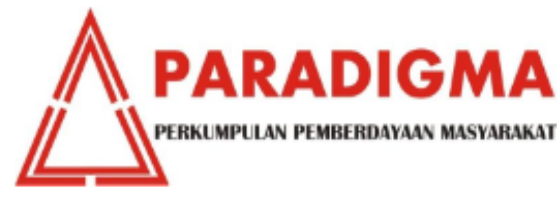

SUSUNAN PERSONEL

PROGRAM SNGOJURUH LESTARI

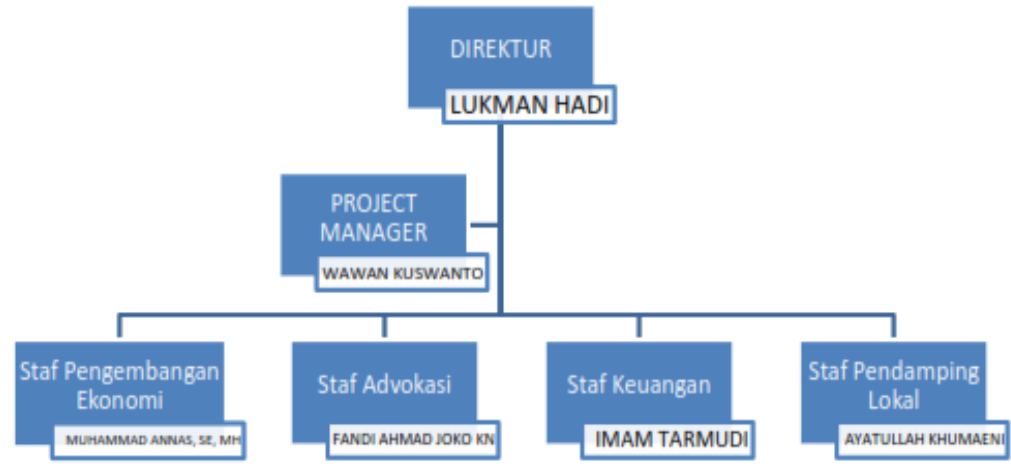

\section{Gambar 1. Struktur Organisasi Program Singojuruh Lestari (Sumber: Dokumentasi, 2019)}

Terdapat beberapa aspek penting dalam pendekatan PAD, diantaranya:

1. Penyusunan perencanaan yang mengedepankan aset $\&$ potensi desa dengan tujuan menggerakan warga untuk mengembangkan diri yang sifatnya bukan pada aspek fisik \& material tetapi juga yang berwujud soial, kelembagaan \& nilai-nilai budaya-spiritual yang tumbuh di desa; 
2. Menemukenali jenis-jenis kekuatan dan aspek-aspek kunci yang dapat menggerakkan masyarakat di tingkat desa dan turut menyelesaikan tantangan yang timbul di tingkat desa; dan

3. Menemukan aktor-aktor penting (baik yang sudah di kenal atau masih tersembunyi) untuk diajak bersama melakukan serangkaian upaya pengembangan desa. pembangunan desa tidak semata menjadi tugas pokok pemerintah desa, melainkan tugas bersama masyarakat.

Definisi desa mandiri jika merujuk aturan yang diterbitkan oleh Kementerian Pembangunan Desa, PDT, dan Transmigrasi adalah Desa Maju yang memiliki kemampuan melaksanakan pembangunan Desa untuk peningkatan kualitas hidup dan kehidupan sebesar-besarnya kesejahteraan masyarakat Desa dengan ketahanan sosial, ketahanan ekonomi, dan ketahanan ekologi secara berkelanjutan. ${ }^{1}$ Dalam hal kemampuan untuk melaksanakan pembangunan desa adalah desa dan seluruh entitas di dalamnya mampu untuk merencanakan, melaksanakan, memantau, mengawasi dan melaporkan pembangunan di desa mereka sendiri. Proses itu dilaksanakan secara partisipatif dan demokratis yang berlandaskan pada tujuan untuk menyejahterakan masyarakat desa.

Undang-Undang Nomor 6 tahun 2014 tentang Desa, desa adalah desa dan desa adat atau yang disebut dengan nama lain, selanjutnya disebut Desa, adalah kesatuan masyarakat hukum yang memiliki batas wilayah yang berwenang untuk mengatur dan mengurus urusan pemerintahan, kepentingan masyarakat setempat berdasarkan prakarsa masyarakat, hak asal usul, dan/atau hak tradisional yang diakui dan dihormati dalam sistem pemerintahan Negara Kesatuan Republik Indonesia. ${ }^{2}$

1 Permendesa No. 2 tahun 2016 tentang Indeks Desa Membangun

2 Pasal 1 angka (1), UU No. 6 tahun 2014 tentang Desa 
Jauh sebelum UU Desa ditetapkan, disebutkan bahwa desa sebagai komuniti yang melandaskan bahwa dalam setiap aspek kehidupan berdesa terdapat tiga subsistem kehidupan, yakni pertama desa sebagai persekutuan sosial budaya. Desa dapat mengatur tata cara hubungan-hubungan antar pihak, baik secara perorangan maupun kelompok berinteraksi satu sama lainnya. Kedua, desa sebagai suatu sistem sosial-politik dan hukum. Di dalamnya terdapat sistem pengaturan yang berkaitan dengan kekuasaan, kepemimpinan, dan juga aturan-aturan yang berkaitan dengan penegakan aturan di dalam komunitas itu. Ketiga, desa sebagai suatu sistem ekonomi. Desa memiliki aturan-aturan yang mengatur penguasaan dan pemanfaatan sumber-sumber ekonomi yang menjadi sumber kehidupan sehari-hari warga masyarakat yang bersangkutan, baik secara perorangan maupun kelompok. ${ }^{3}$

Untuk memajukan kekhasan desa, desa dilekatkan atas dua kewenangan yang orisinil yakni kewenangan atas hak asal usul dan kewenangan berskala lokal desa (subsidiaritas). Dalam upaya menyejahterakan masyarakat, desa berwenang untuk menentukan arah pembangunannya berdasarkan empat bidang pembangunan, yakni penyelenggaraan pemerintahan, pembinaan masyarakat, pembangunan desa dan pemberdayaan masyarakat. Ke semua bidang tersebut, setelah melalui proses konsultasi dengan masyarakat dan pemerintah, dan selanjutnya disinergikan dengan arah pembangunan daerah dan nasional, maka desa berwenang untuk menjalankan pembangunannya sendiri yang bersumber dari dana desa dari transfer pemerintah pusat, pendapatan asli desa, dan kerja sama desa dengan pihak lain yang tidak mengikat.

Sebagai upaya ke arah desa yang sejahtera, mandiri dan demokratis, beberapa faktor penentu yang perlu diperhatikan. Faktor-faktor tersebut yakni faktor tata ruang desa, faktor sumber daya manusia dan alam

${ }^{3}$ Koentjaraningrat, 1985, hal. 155 
(SDM/SDA), pembangunan infrastruktur dan teknologi informasi untuk menunjang pelayanan masyarakat, dan pembangunan sektoral. Dalam konteks tata ruang desa, hal ini merupakan salah satu syarat bagi desa sebelum menetapkan peraturan desa tentang anggaran pendapatan dan belanja desa yang perlu mendapatkan evaluasi dari bupati/walikota. ${ }^{4}$ Oleh sebab itu, secara implisit, dalam perumusan rencana pembangunan menengah desa, desa diwajibkan menyusun tata ruang desa. Ruang desa dalam hal ini tidak hanya fisik semata, melainkan struktur dan pola ruang. Struktur ruang adalah susunan pusat-pusat permukiman dan sistem jaringan prasarana dan sarana yang berfungsi sebagai pendukung kegiatan sosial ekonomi masyarakat yang secara hierarkis memiliki hubungan fungsional. Sedangkan pola ruang adalah distribusi peruntukan ruang dalam suatu wilayah yang meliputi peruntukan ruang untuk fungsi lindung dan peruntukan ruang untuk fungsi budi daya. Dari dua terminologi tersebut penataan dapat disederhanakan tentang bagaimana perencanaan, pemanfaatan dan pengendalian atas ruang. Namun hingga saat ini, desa-desa di Indonesia seolah terabaikan tentang penataan ruang, meski pengakuan atas desa telah dimandatkan berdasarkan definisi tentang desa melalui UU Desa.

Seiring dengan perubahan kebijakan tentang desa, di mana desa secara otonom dimandatkan untuk mengatur rumah tangganya sendiri, maka pengelolaan sumber daya manusia dan alam merupakan kunci untuk mewujudkan desa sejahtera dan mandiri. Karenanya, dua aspek tersebut sekaligus potret yang paling menonjol dalam kehidupan kultur, sosial dan ekonomi desa. Sebagaimana masyarakat desa mayoritas bermata pencaharian pada sektor informal, maka setiap kebijakan desa dapat diarahkan untuk pengelolaan sumber daya alam. Ini merupakan kebutuhan

4 UU Desa Pasal 16 
desa dalam mengelola sumber daya alam yang dapat menjadi kekuatan desa. Namun, sebagai prasyarat, masyarakat juga mampu dalam memahami setiap kewenangan yang dimiliki desa dalam mengelola sumber daya alam yang dimiliki oleh desa. Ini merupakan kunci karena keduanya dipandang saling berkelindan dalam menopang kehidupan berdesa. Oleh sebab itu, dalam setiap formulasi perencanaan pembangunan desa, semua entitas masyarakat desa sudah semestinya diikutsertakan sehingga ruang ke arah desa yang diharapkan dapat terwujud.

Pembangunan infrastruktur dapat dipergunakan perantara dan sekaligus penunjang dalam pengelolaan sumber daya manusia desa dan sumber daya alam. Sebagian desa masih terjebak dalam tujuan pembangunan infrastruktur yang semu. Hal ini berarti pembangunan infrastruktur di desa dirasakan kurang tepat sasaran dan kurang mendesak untuk bagi masyarakat. Pembangunan infrastruktur yang ideal adalah tentang bagaimana infrastruktur yang dibangun berdasarkan kebutuhan masyarakat untuk menunjang akses masyarakat terhadap sumber ekonomi, kesehatan, dan pendidikan. Desa tidak hanya membangun infrastruktur yang hanya menjadi agenda rutin semata, di mana proses minim partisipasi dan pemantauan masyarakat. Terlebih lagi, pembangunan infrastruktur hanya berorientasi pada segelintir entitas yang kurang memperhatikan dampak secara luas di masyarakat. Maka mekanisme pembangunan infrastruktur seperti sebaiknya juga dihindari.

Seiring dengan berkembangnya teknologi informasi, gambaran desa yang terbelakang dengan aktivitasnya yang tradisional dan manual, nampaknya pun semakin pudar. Untuk itu, faktor pemanfaatan teknologi dalam perbaikan layanan masyarakat desa adalah faktor penunjang dalam kemandirian dan kesejahteraan desa. Melalui teknologi, semua aktivitas dalam menunjang pembangunan desa bisa dilaksanakan lebih cepat dan terukur. Terlebih lagi saat ini sebagian besar desa telah mengoperasikan 
teknologi informasi dalam menunjang pelayanan masyarakat untuk layanan diseminasi informasi, pencatatan peristiwa kependudukan, pembangunan infrastruktur, pengelolaan keuangan, administrasi pemerintahan dan lainnya. Melalui teknologi informasi, desa bisa langsung terkoneksi dengan pemerintah pusat untuk perbaikan data dan proses pembangunan yang disampaikan kepada supradesa.

Pemanfaatan aset dan potensi, desa diberikan ruang untuk memaksimalkannya. Oleh sebab itu, pengmbangan sektoral atas kekhasan yang dimiliki desa menjadi faktor penentu dalam memajukan desa. Sebagai panduannya, pemerintah telah menyusun indeks desa membangun, di dalam ada tiga aspek sebagai pengukurnya yakni ketahanan sosial, ekonomi dan ekologi. ${ }^{5}$ Dengan demikian, desa dapat mengembangkan potensinya yang bersifat sektoral. Hal ini untuk menjawab tantangan keragaman aset dan potensi desa yang dimiliki. Adakalanya desa menguatkan sisi ekonomi saja, namun tidak menutup kemungkinan desa mengembangkan ekologinya yang mampu menyejahterakan masyarakatnya.

Berdasarkan faktor-faktor di atas, tentunya, mustahil dapat direalisasikan tanpa adanya prinsip partisipatif dan demokratis yang dipahami oleh semua elemen desa. Dalam konteks administrasi publik, good governance dapat dicirikan dalam tiga hal yakni policy (konten kebijakan), politic (prosedur pelaksanaan kebijakan), dan polity (sistem kelembagaan yang melaksanakan kebijakan). ${ }^{6}$ Ketika hal itu dituangkan dalam praktik berdesa, di mana di dalamnya merupakan kesatuan masyarakat yang berpemerintahan, maka pelaksanaan akuntabilitas, partisipatif dan demokratis merupakan keniscayaan. Tanpa adanya proses emansipatoris dari masyarakat, tujuan desa yang mandiri dan sejahtera akan sulit tercapai.

${ }^{5}$ Permedesa No. 2 tahun 2016 tentang Indeks Pembangunan Desa Pasal 1

${ }^{6}$ Stiker, Gerry. 1998. Governance as theory: five propositions. International Social Science Journal, 1998; 50: 17-28 


\section{Metode}

Dalam mewujudkan imajinasi perubahan yang diharapkan, Perkumpulan Pemberdayaan Masyarakat Paradigma merancang sebuah konsep pembangunan masyarakat desa Benelan Kidul. Asumsi ini didasarkan pada permasalahan-permasalahan yang telah diidentifikasi oleh Perkumpulan Pemberdayaan Masyarakat Paradigma dan PT Tirta Investama, Tbk.

Tabel 1. Konsep Pembangunan Masyarakat Desa Benelan Kidul

\begin{tabular}{|c|c|c|}
\hline $\begin{array}{l}\text { Hasil dan } \\
\text { Kegiatan }\end{array}$ & Indikator & Target \\
\hline $\begin{array}{l}\text { Hasil 1. } \\
\text { Membaiknya } \\
\text { pemahaman } \\
\text { masyarakat } \\
\text { dan } \\
\text { pemerintah } \\
\text { desa dalam } \\
\text { perilaku hidup } \\
\text { sehat dan } \\
\text { sejahtera } \\
\text { melalui proses } \\
\text { pembangunan } \\
\text { desa yang } \\
\text { inklusif dan } \\
\text { partisipatif }\end{array}$ & $\begin{array}{l}\text { 1. Kelompok masyarakat desa } \\
\text { bersama pemerintah desa } \\
\text { saling berkolaborasi dalam } \\
\text { pelaksanaan pendataan dan } \\
\text { perumusan instrumen } \\
\text { pendataan desa, khususnya } \\
\text { dalam aspek sosial, } \\
\text { ekonomi, kesehatan dan } \\
\text { lingkungan; } \\
\text { 2. Data desa sasaran mengenai } \\
\text { kewenangan berskala lokal } \\
\text { desa, aset dan potensi, } \\
\text { gagasan kelompok yang } \\
\text { termarjinalkan, indikator } \\
\text { kesejahteraan lokal desa } \\
\text { dan pelayanan publik dalam } \\
\text { aspek sosial, ekonomi, } \\
\text { kesehatan dan lingkungan; } \\
\text { 3ata desa yang digali oleh } \\
\text { masyarakat bersama } \\
\text { pemerintah desa ke dalam } \\
\text { dokumen rencana } \\
\text { pembangunan jangka } \\
\text { menengah desa } \\
\text { (RPJMDesa); } \\
\text { 4. Prasarana dan akses ke arah } \\
\text { hidup sehat dan sejahtera di } \\
\text { desa sasaran; dan } \\
\text { 5. Jumlah masyarakat yang } \\
\text { mendapatkan pembinaan } \\
\text { penyuluhan dan pembinaan } \\
\text { mengenai hidup sehat dan } \\
\text { sejahtera }\end{array}$ & $\begin{array}{l}\text { 1. Berdirinya organisasi masyarakat } \\
\text { berbasis komunitas yang terdiri dari } \\
\text { semua elemen desa sebagai tim } \\
\text { pembaharu desa (TPD) di setiap desa } \\
\text { sasaran program; } \\
\text { 2. Desa sasaran program memasukkan } \\
\text { usulan kegiatan untuk perbaikan } \\
\text { kesehatan masyarakat melalui } \\
\text { pengembangan air bersih, sanitasi dan } \\
\text { hieginitas serta pemberdayaan ekonomi } \\
\text { ke dalam dokumen rancangan } \\
\text { RPJMDesa/RKPDesa/APBDes } \\
\text { 3. Draft peraturan desa tentang RPJMDesa } \\
\text { yang memuat tentang kewenangan, aset } \\
\text { dan potensi desa, gagasan kelompok } \\
\text { yang termarginalkan, kesejahteraan } \\
\text { lokal desa, dan pelayanan publik; } \\
\text { 4. Adanya infrastruktur fisik dan sosial } \\
\text { ekonomi yang dapat berkontribusi pada } \\
\text { peningkatan kehidupan masyarakat } \\
\text { yang lebih sejahtera dan sehat dengan } \\
\text { mencakup target sebagai berikut: } \\
\text { a. Adanya } 1 \text { jamban baru yang dikelola } \\
\text { oleh komunitas di fasilitas umum; } \\
\text { b. } 10 \text { rumah mendapatkan dukungan } \\
\text { material untuk pembangunan jamban } \\
\text { keluarga; } \\
\text { c. Adanya instalasi pengelolaan sampah } \\
\text { berbasis komunitas oleh BUMDesa; } \\
\text { d. Adanya rencana strategis pengelolaan } \\
\text { mata air dan irigasi; } \\
\text { 5. Adanya } 100 \text { kepala keluarga } \\
\text { memperoleh manfaat dari proyek ini. }\end{array}$ \\
\hline
\end{tabular}




\begin{tabular}{|c|c|c|}
\hline $\begin{array}{l}\text { Hasil dan } \\
\text { Kegiatan }\end{array}$ & Indikator & Target \\
\hline $\begin{array}{l}\text { Keluaran 1.1 } \\
\text { Tersedianya } \\
\text { data desa } \\
\text { dalam aspek } \\
\text { sosial, ekonomi, } \\
\text { kesehatan dan } \\
\text { lingkungan } \\
\text { sebagai bahan } \\
\text { dalam } \\
\text { penyusunan } \\
\text { rencana } \\
\text { pembangunan } \\
\text { desa } \\
\text { (RPJMDesa) } \\
\text { pada tahun } \\
\text { mendatang } \\
\text { yang disusun } \\
\text { oleh } \\
\text { masyarakat } \\
\text { dan } \\
\text { pemerintah } \\
\text { desa secara } \\
\text { partisipatif dan } \\
\text { inklusif }\end{array}$ & $\begin{array}{l}\text { 1. Jumlah masyarakat desa } \\
\text { sasaran program yang } \\
\text { berpartisipasi dalam } \\
\text { pelatihan perencanaan } \\
\text { apresiatif desa; } \\
\text { 2. Instrumen survei dan } \\
\text { sensus yang dikembangkan } \\
\text { oleh masyarakat dan } \\
\text { pemerintah desa } \\
\text { berdasarkan skala lokal } \\
\text { desa; } \\
\text { 3. Kapasitas masyarakat desa } \\
\text { sasaran program yang } \\
\text { terlatih dalam proses } \\
\text { penggalian dan analisis data } \\
\text { di desanya sendiri atas } \\
\text { pendampingan mitra; } \\
\text { 4. Jumlah masyarakat desa } \\
\text { sasaran program yang } \\
\text { memahami dalam } \\
\text { penyusunan produk hukum } \\
\text { di level desa; } \\
\text { 5. Jumlah rancangan produk } \\
\text { hukum di level desa sebagai } \\
\text { dasar pelaksanaan } \\
\text { pembangunan desa; dan } \\
\text { 6olaborasi antara } \\
\text { masyarakat dan pemerintah } \\
\text { desa berjalan sinergis dalam } \\
\text { pelaksanaan pembangunan } \\
\text { desa }\end{array}$ & $\begin{array}{l}\text { Terbentuknya tim pembaharu yang } \\
\text { sebanyak } 25 \text { orang di setiap desa sasaran } \\
\text { program; } \\
\text { Adanya PERDES mengenai indikator } \\
\text { kesejahteraan lokal desa, kewenangan } \\
\text { desa, aset dan potensi desa, serta gagasan } \\
\text { kelompok yang termarginalkan } \\
\text { Adanya PERKADES mengenai layanan } \\
\text { publik } \\
\text { Dokumen laporan tim pembaharu desa } \\
\text { dijadikan sebagai bahan masukan ke } \\
\text { dalam penyusunan RPJMDesa yang } \\
\text { berbasis pada aspek sosial, ekonomi, } \\
\text { kesehatan dan lingkungan; } \\
\text { Adanya rencana kerja strategi advokasi } \\
\text { oleh tim pembaharu desa; } \\
\text { Adanya rancangan PERDES RPJMDesa di } \\
\text { setiap desa sasaran program } \\
\text { Adanya PERDES tentang RKPDesa dan } \\
\text { APBDesa di setiap desa sasaran program; } \\
\text { dan } \\
\text { Pertemuan rutin antara tim pembaharu } \\
\text { desa dan pemerintah desa }\end{array}$ \\
\hline $\begin{array}{l}\text { Keluaran } 1.2 \\
\text { Terciptanya } \\
\text { akses } \\
\text { masyarakat } \\
\text { Desa Benelan } \\
\text { Kidul yang } \\
\text { sehat dan } \\
\text { sejahtera }\end{array}$ & $\begin{array}{l}\text { 1. Jumlah masyarakat desa } \\
\text { sasaran program yang } \\
\text { berpartisipasi dalam } \\
\text { sosialisasi hidup sehat dan } \\
\text { sejahtera; } \\
\text { 2. Usulan dan rencana kerja } \\
\text { masyarakat dalam } \\
\text { perbaikan terhadap akses } \\
\text { prasarana ke arah hidup } \\
\text { sehat dan sejahtera } \\
\text { 3. Jumlah masyarakat desa } \\
\text { sasaran program yang } \\
\text { memahami tentang } \\
\text { pengelolaan air dan sanitasi; } \\
\text { 4. Pengerjaan dan perawatan }\end{array}$ & $\begin{array}{l}\text { 1. Sebanyak } 100 \text { kepala keluarga } \\
\text { mendapatkan pemahaman mengenai } \\
\text { hidup sehat dan sejahtera; } \\
\text { 2. Adanya daftar usulan masyarakat Desa } \\
\text { Benelan Kidul untuk prasarana hidup } \\
\text { sehat dan sejahtara dan pengelolannya; } \\
\text { 3. Adanya rencana kerja komunitas } \\
\text { pelaksana untuk pembangunan saluran } \\
\text { air; } \\
\text { 4. Adanya pembangunan saluran air } \\
\text { dengan dimensi dan pembangunan } \\
\text { debit air sebanyak } 2 \text { titik dan jamban } \\
\text { sebanyak } 10 \text { titik; } \\
\text { 5. BUMDesa memiliki model bisnis yang } \\
\text { mandiri dengan melibatkan warga }\end{array}$ \\
\hline
\end{tabular}




\begin{tabular}{|c|c|c|}
\hline & $\begin{array}{l}\text { saluran air, debit air oleh } \\
\text { komunitas; } \\
\text { 5. Kapasitas SDM pengelola } \\
\text { BUMDes } \\
\text { 6. Aset BUMDesa terkeloa }\end{array}$ & $\begin{array}{l}\text { masyarakat Desa Benelan Kidul; dan } \\
\text { 6. BUMDesa dikelola secara profesional } \\
\text { dengan memegang prinsip-prinsip di } \\
\text { dalamnya }\end{array}$ \\
\hline
\end{tabular}

Sumber: Dokumentasi, 2019

Untuk mewujudkan 5 aspek Perencanaan Apresiasi Desa (PAD) di atas, aktoraktor Tim Pembaharu Desa (TPD) di Desa Benelan Kidul dikelompokkan menjadi 5 tim, yaitu:

\section{T i m Kewenangan Desa}

Semua program atau kegiatan pembangunan desa harus mengacu pada kewenangan desa berdasarkan prakarsa masyarakat, hak asal usul, dan adat istiadat desa. Karena pentingnya kewenangan desa, maka semua data, informasi,gagasan, layanan, hingga pelaksanaan pembangunan di desa yang bersifat asal usul dan berskala desa harus tercakup dalam dokumen kewenangan desa. Tim kewenangan desa perlu mengidentifikasi kewenangan berdasarkan hak asal-usul dan kewenangan lokal berskala desa.

Kewenangan desa berdasarkan hak asal-usul adalah hak yang masih hidup dan sesuai dengan perkembangan kehidupan masyarakat. Kewenangan ini dapat berupa adat istiadat yang menjadi tradisi sebelum tahun 1979. Tradisi tersebut mencakup cara berdesa dalam berpemerintahan, pembangunan, pembinaan kemasyarakatan, hingga pemberdayaan masyarakat. Kewenangan lokal berskala desa merupakan kewenangan untuk mengatur dan mengurus kepentingan masyarakat Desa yang telah dijalankan oleh Desa atau mampu dan efektif dijalankan oleh Desa atau yang muncul karena perkembangan Desa dan prakasa masyarakat Desa. 
Tim kewenangan desa perlu mengidentifikasi (menemukan dan mengenali) sejarah desa meliputi hal-hal yang biasa dilakukan desa dalam aspek kepemimpinan, tata kelola, keamanan, budaya, dan aspek lainnya yang berhubungan dengan kegiatan berdesa. Selain itu, tim kewenangan desa juga perlu mengidentifikasi tata kelola pemerintahan desa sebelum tahun 1979. Mengapa 1979? karena Desa mulai diseragamkan pemerintahannya sejak disahkannya Undang-undang nomor 5 tahun 1979 tentang Pemerintahan Desa. Kemudian, kewenangan desa yang beragam kembali diakui melalui asas rekognisi pada Undang-undang nomor 6 tahun 2014 tentang Desa (UU Desa).

Daftar kewenangan desa yang sudah teridentifikasi kemudian dikelompokkan dalam 4 bidang, yaitu bidang penyelenggaraan pemerintahan desa, pelaksanaan pembangunan desa, pembinaan kemasyarakatan desa, dan pemberdayaan masyarakat desa. Dokumen kewenangan desa merupakan dokumen yang disahkan melalui peraturan desa. Peraturan Desa yang mengatur kewenangan Desa berdasarkan hak asal usul dan kewenangan berskala lokal Desa pelaksanaannya diawasi oleh masyarakat Desa dan Badan Permusyawaratan Desa.

\section{Tim Aset dan Potensi}

Aset dan potensi yang ada di desa perlu diidentifikasi untuk menghasilkan rekomendasi optimalisasi aset dalam bentuk program/kegiatan. Aset di sini bukan hanya aset yang dapat diindera, tapi juga aset sosial yang tersemat dalam individu, kelompok, dan desa. Aset dipetakan dalam 7 jenis, yaitu:
a) Aset Sumber Daya Alam;
b) Aset Sumber Daya Manusia;
c) Aset Kelembagaan;
d) Aset Keuangan; 
e) Aset Fisik;

f) Aset Sosial; dan

g) Aset Spiritual dan Budaya;

Setiap aset dipastikan mempunyai potensi untuk dikembangkan, maka tim perlu menggali kedalaman informasi mengenai aset, meliputi: 1) Status kepemilikan (Aset Desa, Aset Kelompok, Aset Masyarakat, atau Aset Pihak Luar Desa); 2) Kondisi saat ini (misalnya: penguasaannya, pemanfaatannya, cara pemenuhannya, kualitas, pengaturannya, hal-hal yang memengaruhi kondisi saat ini); 3) Potensi yang bisa dikembangkan atas aset; hingga 4) Tantangan pengembangan aset.

Strategi pengembangan aset kemudian diturunkan ke dalam bentuk program atau kegiatan pembangunan desa atau pembidangan (4 bidang kewenangan desa). Dari tim ini akan muncul strategi pengembangan berbasis pada aset, bukan berbasis masalah semata. Data aset dan potensi desa dapat disahkan melalui peraturan desa tentang aset dan potensi desa atau rencana tata ruang desa.

\section{Tim Kesejahteraan Desa}

Amanah utama pembangunan adalah peningkatan kesejahteraan masyarakat. Untuk mengetahui keberhasilan pembangunan, maka tingkat kesejahteraan masyarakat perlu diukur. Ukuran tingkat kesejahteraan desa dapat disesuaikan dengan kebutuhan desa dan dapat dimutakhirkan secara periodik. Pada tahap ini, tim diajak memetakan ukuran kesejahteraan masyarakat. Ukuran atau indikator kesejahteraan ini disusun berdasarkan kebutuhan lokal desa untuk memetakan kelas sosial desa berbasis kesejahteraan. Karena konteksnya adalah lokal, ukuran ini diprioritaskan untuk menilai tingkat kesejahteraan masyarakat pada level desa. Bisa saja ukuran kesejahteraan satu desa akan berbeda dengan desa lainnya, karena desa bersifat unik. 
Penyusunan ukuran dimulai dari memetakan berapa tingkatan/kelas sosial yang akan dipetakan. Sebagai contoh, terdapat 3 kelas sosial yang terdiri dari pra sejahtera, sejahtera, dan sangat sejahtera. Desa bisa saja mengelompokkan menjadi 4 atau 5 kelas sosial. Selanjutnya dipetakan ukuran yang memengaruhi tingkat kesejahteraan masyarakat mulai dari yang memengaruhi paling tinggi hingga terendah. Setelah setiap ukuran kesejahteraan dipetakan dan diurutkan, petakan nilai ukuran pada setiap kelas sosial dengan setiap ukuran yang memengaruhi tingkat kesejahteraan. Misalnya ukuran kesejahteraan dalam aspek penghasilan per bulan, tentukan nilai penghasilan pada setiap kelompok sosial. Contoh dapat di lihat pada tabel di bawah ini:

Tabel 2. ukuran kesejahteraan dalam aspek penghasilan per bulan

\begin{tabular}{|l|l|l|ll}
\hline \multirow{2}{*}{$\begin{array}{c}\text { Ukuran/ } \\
\text { Indikator }\end{array}$} & \multicolumn{3}{|c}{ Kelas Sosial } \\
\cline { 2 - 5 } & \multicolumn{1}{|c}{ Pra sejahtera } & \multicolumn{2}{c}{ Sejahtera } & \multicolumn{2}{c}{ Sangat } \\
\hline $\begin{array}{l}\text { Penghasilan } \\
\text { per bulan }\end{array}$ & $\begin{array}{l}\text { kurang dari } \\
1,000,000\end{array}$ & $\begin{array}{l}1,000,000 \text { sampai } \\
2,500,000\end{array}$ & lebih & $2,500,000$ \\
\hline ...dst & & & \\
\hline
\end{tabular}

Sumber: Dokumentasi, 2019

Setelah ukuran dan nilai sudah terpetakan, selanjutnya dilakukan pembobotan dan uji simulasi ukuran. Ukuran kesejahteraan selanjutnya dapat didiskusikan dan disempurnakan dengan melibatkan banyak lagi warga untuk semakin memperkuat ukuran dan nilai kesejahteraan. Setelah ukuran disepakati, maka tim dapat malakukan sensus kepada setiap keluarga di desa. Berikut adalah tahapan pemetaan kesejahteraan masyarakat desa:

a. Penyusunan ukuran/indikator;

b. Penyepakatan dan penetapan ukuran/indikator (melalui musyawarah desa); 
c. Sensus keluarga;

d. Pengolahan data;

e. Publikasi (masukan publik);

f. Verifikasi dan perbaikan;

g. Penyempurnaan (hasil perbaikan);

h. Menyusun dokumen dan visualisasi kesejahteraan desa; dan

i. Penetapan data kesejahteraan desa (melalui musyawarah desa).

Data kesejahteraan desa dapat dimutakhirkan setiap tahun atau menurut kebutuhan desa untuk menilai sejauh mana keberhasilan pemerintah desa dalam meningkatkan kesejahteraan masyarakat.

\section{T i m Gagasan Kelompok Marjinal}

Rencana pembangunan desa kerap kali dibahas menggunakan konsep ruang terundang (invited space). Untuk menghimpun usulan atau gagasan pembangunan dari semua lapisan masyarakat tanpa terkecuali, penggalian gagasan dari kelompok yang sejauh ini terpinggirkan (marjinal) perlu dilakukan. Kriteria kelompok marjinal di satu desa dengan desa lainnya bisa saja berbeda. Maka dari itu, tim perlu memetakan terlebih dahulu daftar kriteria kelompok marginal berikut jenisnya.

Maksud penggalian gagasan kelompok marjinal bukan hanya akan menggali usulan mereka, tetapi juga memetakan potensi dan kontribusi mereka terhadap pembangunan desa ke depan. Daftar usulan dapat diurutkan berdasarkan prioritas kebutuhan.

\section{T i m Perbaikan Layanan Publik}

Penilaian masyarakat terhadap mutu layanan publik di desa dapat diukur melalui survei perbaikan layanan publik. Survei ini memuat aspekaspek layanan meliputi administrasi publik, barang publik, hingga jasa publik. Tim diajak mengdentifikasi daftar layanan prioritas yang perlu dinilai untuk kemudian diperbaiki. 
Kelima tahapan/kelompok tersebut harapannya akan memperkuat partisipasi masyarakat desa mulai dari tahapan perencanaan pembangunan desa. Upaya ini juga akan mendorong peran masyarakat bukan hanya menjadi penerima program/kegiatan pembangunan desa, tapi juga menjadikan masyarakat sebagai pelaku perencana dengan melibatkan mereka pada setiap kelompok PAD. Kelima kelompok tersebut dapat disebut sebagai Tim Pembaharu Desa (TPD). Hasil dari pendekatan ini sedikitnya dapat berupa:

a. Perdes tentang Kewenangan Desa;

b. Perdes tentang Aset dan Potensi Desa;

c. Perdes tentang Data Kesejahteraan Masyarakat Desa;

d. Daftar Gagasan Kelompok Marginal;

e. Janji perbaikan layanan pemerintah desa (maklumat) kepada masyrakat.

Data dan dokumen yang dihasilkan TPD dapat menjadi acuan tim penyusun RPJM Desa untuk menyusun dokumen perencanaan berbasis data aktual yang mengapresiasi aset dan prakarsa masyarakat desa.

\section{Hasil dan Diskusi}

Metodologi evaluasi kegiatan program pendampingan ini menggunakan pendekatan kualitatif dengan teknik analisis konten. Adapun mekanisme pengumpulan data dibagi menjadi dua sumber yakni primer dan sekunder. Sumber primer meletakkan pada data yang diperoleh dari dokumen laporan program dan wawancara secara mendalam kepada para pihak utama yang bersinggungan dengan pelaksanaan program. Sementara sumber sekunder mempercayakan pada buku, jurnal, publikasi media dan sumber pendukung lain yang memiliki akurasi dan validasi sumber. 
Tabel 2. Program Kerja Pendampingan

\begin{tabular}{|c|c|c|c|}
\hline No & Tanggal & Nama Kegiatan & Hasil \\
\hline 1 & $\begin{array}{l}\text { Rabu } 11 \\
\text { Desember } \\
2019\end{array}$ & $\begin{array}{l}\text { Rapat persiapan } \\
\text { Pelaksanaan } \\
\text { Program }\end{array}$ & $\begin{array}{l}\text { 1. Semua Tim memahami desain prgram, } \\
\text { output program dan outcome program. } \\
\text { 2. Semua Tim memahami tugas dan tanggung } \\
\text { jawabnya dalam melaksanakan program. } \\
\text { 3. Tersusunya RTL: } \\
\text { a. Koordinasi dengan Pemdes dan Tokoh } \\
\text { Masyarakat untuk sosialisai program. Tgl } \\
\text { 12-15 Desember } 2019 \\
\text { b. Persiapan pelatihan apresiasi desa 15-25 } \\
\text { Desember 2019.. } \\
\text { c. Pelatihan Apresiasi Desa tgl 28-29 } \\
\text { Desember } 2019\end{array}$ \\
\hline 2 & $\begin{array}{l}\text { Kamis, } 12 \\
\text { Desember } \\
2019\end{array}$ & $\begin{array}{lr}\text { Koordinasi } & \text { dengan } \\
\text { Pemdes } & \text { untuk } \\
\text { Sosialisasi Program }\end{array}$ & $\begin{array}{l}\text { 1. Paradigma mensosialisikan ke pemdes / } \\
\text { sekdes } \\
\text { 2. Pemerintah desa berkomitmen bekerja sama } \\
\text { dan mendukung jalanya program }\end{array}$ \\
\hline 3 & $\begin{array}{l}\text { Tgl. } 15-25 \\
\text { Desember } \\
2019\end{array}$ & $\begin{array}{l}\text { Persiapan pelatihan } \\
\text { apresiasi desa }\end{array}$ & $\begin{array}{l}\text { Persiapan Pelatihan Apresiasi Desa dipersiapkan } \\
\text { oleh semua Tim }\end{array}$ \\
\hline 4 & $\begin{array}{l}\text { Tgl 28-29 } \\
\text { Desember } \\
2019\end{array}$ & $\begin{array}{l}\text { Pelatihan Apresiasi } \\
\text { Desa }\end{array}$ & $\begin{array}{l}\text { Hasil Kegiatan Pelatihan } \\
\text { 1. Pemerintah desa memberikan dukungan } \\
\text { penuh terhadap berjalannya kegiatan } \\
\text { 2. Peserta mendapat pengetahuan dan keahlian } \\
\text { untuk melakukan kegiatan pengkajian } \\
\text { kondisi desa sesuai dengan kelas masing } \\
\text { masing } \\
\text { 3. Di dapatkan data awal mengenai aset dan } \\
\text { potensi,.... } \\
\text { Kesimpulan dari kegiatan ini acara berjalan } \\
\text { dengan lancar sesuai dengan output dan } \\
\text { outcome yang diharapakan. }\end{array}$ \\
\hline 5 & $\begin{array}{l}\text { Tgl } 13 \\
\text { Januari } 2020\end{array}$ & $\begin{array}{l}\text { Musyawarah desa } \\
\text { untuk penetapan } \\
\text { instrumen survey } \\
\text { dan pembekalan } \\
\text { petugas survey }\end{array}$ & $\begin{array}{l}\text { Hasil dari rapat. } \\
\text { 1. Pemdes sepakat dalam pengkajian desa } \\
\text { menggunakan data hasil survey. } \\
\text { 2. TPD berkomitmen melakukan survey untuk } \\
\text { menengkapi data. } \\
\text { 3. TPD mendapat alat survey dari paradigma. } \\
\text { Kesimpulan } \\
\text { 1. Kegiatan Musyawarah desa untuk penetapan } \\
\text { instrumen survey dan pembekalan petugas } \\
\text { survey dapat berjalan Lancar dan sukses } \\
\text { 2. Peserta memahami tugas dan tanggung } \\
\text { jawabnya } \\
\text { 3. Kegiatan dapat berjalan sesuai jadwal }\end{array}$ \\
\hline
\end{tabular}




\begin{tabular}{|c|c|c|c|}
\hline No & Tanggal & Nama Kegiatan & Hasil \\
\hline 6 & $\begin{array}{l}\text { Selasa, } 27 \\
\text { Januari } 2020\end{array}$ & $\begin{array}{l}\text { Workshop } \\
\text { Pengelolaan } \\
\text { Sampah dan } \\
\text { Merumuskan } \\
\text { system pengelolaan } \\
\text { sampah desa }\end{array}$ & $\begin{array}{l}\text { Hasil dari Worhshop: } \\
\text { 1. Di setiap KK ada dua tong sampah, satu } \\
\text { untuk sampah organik dan satunya lagi buat } \\
\text { sampah an organik. } \\
\text { 2. Sampah an organik di setorkan di tempat } \\
\text { penampungan sampah sementara atau Bank } \\
\text { Sampah. } \\
\text { 3. Tempat penampungan sampah sementara } \\
\text { Bank Sampah merupakan unit Bumdes. } \\
\text { 4. Sampah an organik yang mempunyai nilai } \\
\text { ekonomi ditabung oleh warga di bank } \\
\text { sampah. } \\
\text { 5. Sampah organik diseleseikan sendiri wilayah } \\
\text { RT setempat di proses menjadi kompos. } \\
\text { 6. Sampah yang sudah terlanjur menumpuk } \\
\text { ditepi sungai dan tempat lain harus } \\
\text { dibersihkan dengan kerja bakti. } \\
\text { Kesimpulan } \\
\text { 1. Masyarakat menyadari masalah sampah } \\
\text { harus ditangani bersama semua elemen } \\
\text { masyarakat. } \\
\text { 2. Hidup bersih dan sehat menjadi dambaan } \\
\text { seluruh warga masyarakat. }\end{array}$ \\
\hline 7 & $\begin{array}{l}\text { Selasa, } 28 \\
\text { Januari } 2019\end{array}$ & $\begin{array}{l}\text { Diskusi } \\
\text { pembentukan } \\
\text { Karang Taruna }\end{array}$ & $\begin{array}{l}\text { Kesimpulan } \\
\text { 1. Sudah berhasil Pembentukan Pengurus } \\
\text { Karang Taruna dan divisi divisinya. } \\
\text { 2. Rapat berjalan sukses dan lancar dan } \\
\text { mendapatka dukungan dari semua pihak }\end{array}$ \\
\hline 8 & $\begin{array}{l}\text { Selasa, } 4 \\
\text { Februari } \\
2020\end{array}$ & $\begin{array}{lr}\text { Rapat } & \text { Program } \\
\text { Kerja } & \text { Karang } \\
\text { Taruna } & \text { (Tim } \\
\text { Pembaharu } & \text { Desa ) } \\
\text { mempersiapkan } \\
\text { kegiatan sosialisasi } \\
\text { hidup sehat dan } \\
\text { sejahtera }\end{array}$ & $\begin{array}{l}\text { Hasil diskusi : } \\
\text { 1. Pengurus dan Anggota karang taruna paham } \\
\text { posisi mereka secara hukum; } \\
\text { 2. Pengurus dan Anggota Karang taruna } \\
\text { memahami tugas dan tanggungjawabnya; } \\
\text { 3. Kesepakatan untuk menyusun program } \\
\text { tahunan di pertemuan berikutnya; } \\
\text { 4. Merumuskan rencana kegiatan sosialisasi } \\
\text { hidup sehat Dengan kesepkatan: } \\
\text { a. Sosialisasi didakan di enam dusun } \\
\text { b. Karangtaruna sebagi panitia } \\
\text { c. Paradigma dan Aqua memberikan } \\
\text { dukungan material } \\
\text { d. Dalam kegiatan ada Tiga narasumber } \\
\text { 1) Lima Pilar hidup sehat, nara sumber } \\
\text { dari puskesmas } \\
\text { 2) Tata cara pemilahan Sampah, nara } \\
\text { sumber dari karangtaruna } \\
\text { 3) Sistem pengelolaan sampah desa, nara } \\
\text { sumber Dario kepala dusun }\end{array}$ \\
\hline
\end{tabular}




\begin{tabular}{|c|c|c|c|}
\hline No & Tanggal & Nama Kegiatan & Hasil \\
\hline 9 & $\begin{array}{l}\text { Jum'at } 14 \\
\text { Februari } \\
2020\end{array}$ & $\begin{array}{l}\text { Musrengbangdes } \\
\text { Penetapan } \\
\text { Penyusunan } \\
\text { RPJMDes }\end{array}$ & $\begin{array}{l}\text { Kegiatan Musrengbangdes Penetapan } \\
\text { Penyusunan RPJMDes juga difasilitasi oleh } \\
\text { Paradigma. Hadir dalam Kegiatan ini antara lain: } \\
\text { 1. Perwakilan dari Camat Singojuruh } \\
\text { 2. Ketua BPD Desa Benelan Kidul } \\
\text { 3. Kepala Desa Benelan Kidul } \\
\text { 4. Sekretaris Desa Benelan Kidul } \\
\text { 5. Seluruh Kepala Dusun dan Perangkat desa } \\
\text { 6. Seluruh elemen desa PKK, Karang Taruna, } \\
\text { Tokoh Agama dan Tokoh Masyarakat. }\end{array}$ \\
\hline 10 & $\begin{array}{l}\text { Senin } 24 \\
\text { Februari } \\
2020\end{array}$ & $\begin{array}{l}\text { Sosialisasi Hidup } \\
\text { Sehat dan Sanitasi di } \\
\text { Desa Benelan }\end{array}$ & $\begin{array}{l}\text { Acara Sosialisasi Hidup Sehat dan Sanitasi di } \\
\text { Desa Benelan kidul di laksanakan di enam dusun } \\
\text { di mulai di Dusun Gombol jam 19.00. pada } \\
\text { tanggal } 24 \text { Februari 2020, selajutnya di bergilir } \\
\text { tiap malam selama enam hari. Sasaran kegiatan } \\
\text { ini adalah ibu ibu rumah tangga yang tergabung } \\
\text { dalam kelompok jamaah yasin ibu ibu. Dan } \\
\text { melibatkan penyuluh kesehatan dari } \\
\text { PUSKESMAS Singujuruh sebagai TIM Pemateri. }\end{array}$ \\
\hline 11 & $\begin{array}{l}\text { Jum'at } 6 \\
\text { Maret } 2020\end{array}$ & $\begin{array}{lr}\text { Kujungan } & \text { Kerja dan } \\
\text { Study } & \text { Banding } \\
\text { BUMDes Benelan } \\
\text { Kidul di PT Indra } \\
\text { Jaya Pasuruan. }\end{array}$ & $\begin{array}{l}\text { BUMDES Benelan Kidul mengirim atau } \\
\text { sebaliknya PT. INDRA JAYA menerima AVFAL } \\
\text { PET dari BUMDES. Dalam bentuk sampah yang } \\
\text { sudah di press. }\end{array}$ \\
\hline 12 & $\begin{array}{l}\text { Sabtu } 7 \\
\text { Maret } 2020\end{array}$ & $\begin{array}{lr}\text { Kujungan } & \text { Kerja } \\
\text { daan Study } & \text { Banding } \\
\text { BUMDes } & \text { Benelan } \\
\text { Kidul di } & \text { BUMDes } \\
\text { Kerto Raharjo Desa } \\
\text { Sanankerto } \\
\text { Kecamatan } & \\
\text { Kab.Malang } & \\
\end{array}$ & $\begin{array}{l}\text { Banyak ilmu yang diserap oleh BUMDes Benelan } \\
\text { Kidul dari BUMDes Kertoraharjo berkaitan } \\
\text { dengan manajemen BUMDes dan Pengelolaan } \\
\text { potensi desa. }\end{array}$ \\
\hline 13 & $\begin{array}{l}\text { Senin, } 12 \\
\text { Maret } 2020\end{array}$ & $\begin{array}{l}\text { Workshop } \\
\text { Pembentukan Bank } \\
\text { Sampah dan } \\
\text { Penyerahan } \\
\text { bantuan } \\
\text { Investor PT Tirta } \\
\text { Investama berupa } \\
\text { pembangunan } \\
\text { jamban umum dan } \\
\text { jamban keluarga } \\
\text { untuk 28 KK. }\end{array}$ & 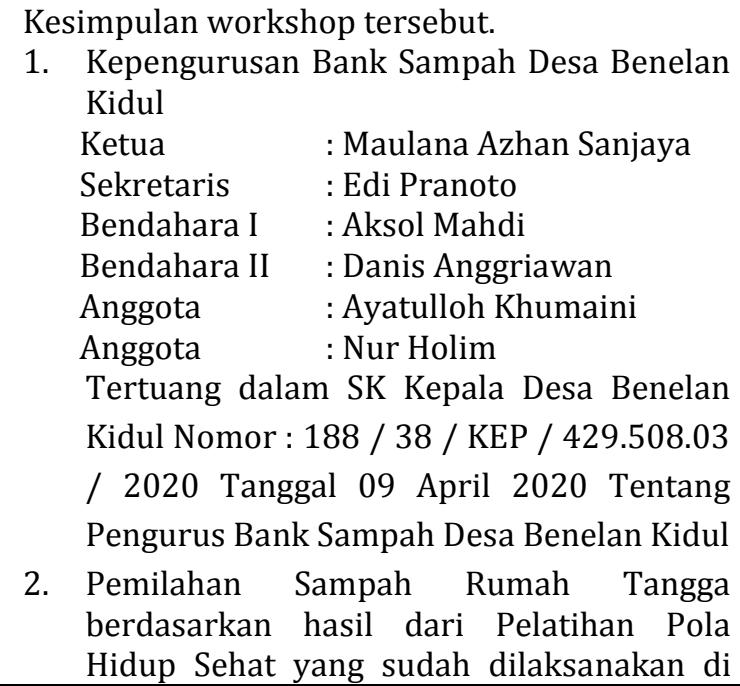 \\
\hline
\end{tabular}




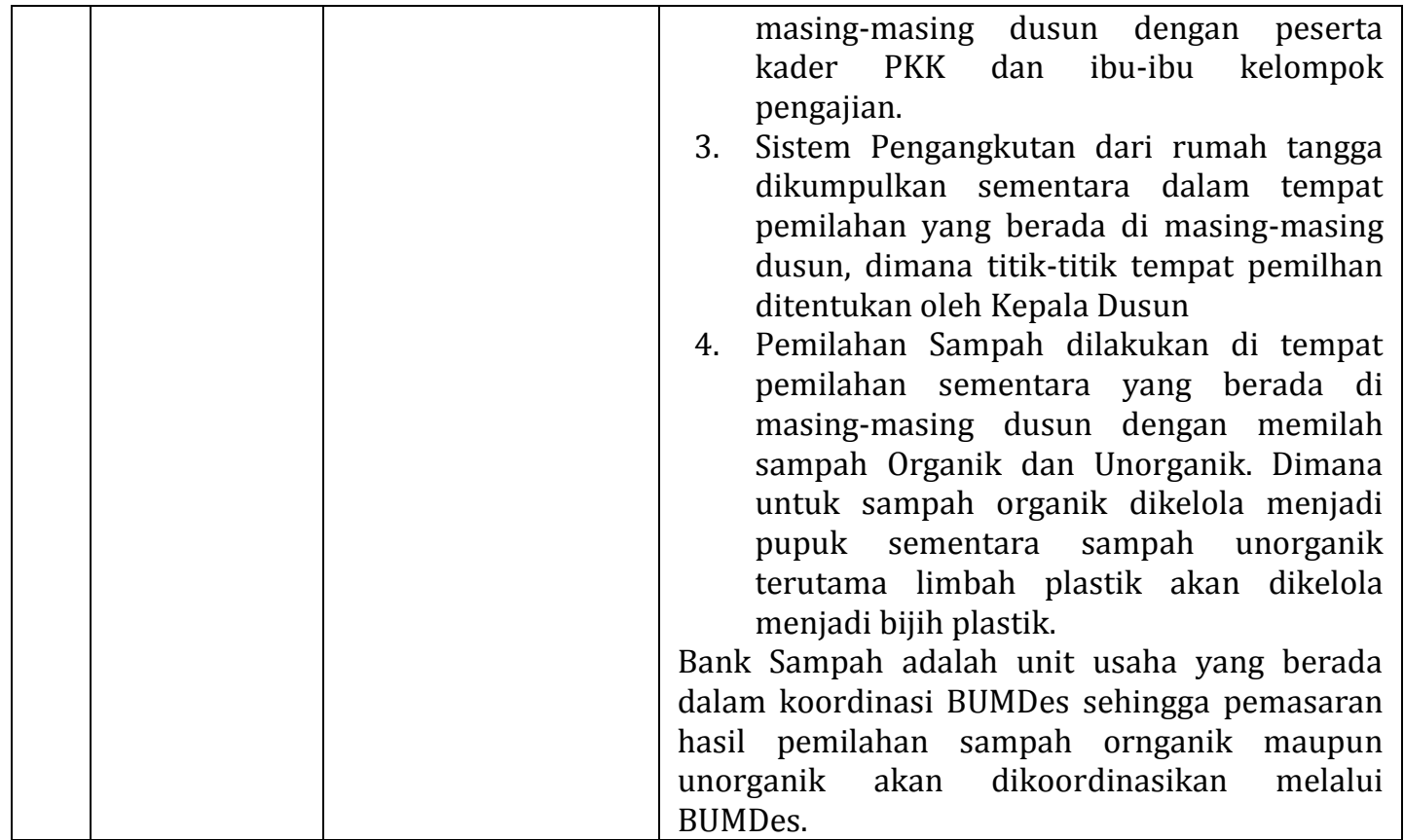

Sumber: Dokumentasi, 2020

Proses penggalian data, peneliti akan mewawancarai beberapa pihak secara lansung yakni sebagai berikut:

a. Pemerintah desa Benelan Kidul;

b. Badan Permusyawaratan Desa Benelan Kidul;

c. Karang Taruna Desa;

d. Perwakilan Kecamatan Singojuruh;

e. Masyarakat sipil/NGO di lokasi program; dan

f. Para pihak yang relevan atau penerima manfaat atas pelaksanaan program community development.

\section{Simpulan}

Masyarakat menyadari masalah sampah harus ditangani bersama semua elemen masyarakat, Hidup bersih dan sehat menjadi dambaan seluruh warga masyarakat. Pemilahan Sampah Rumah Tangga berdasarkan hasil dari Pelatihan Pola Hidup Sehat yang sudah dilaksanakan di masing-masing dusun dengan peserta kader PKK dan ibu-ibu kelompok pengajian. Sistem 
Pengangkutan dari rumah tangga dikumpulkan sementara dalam tempat pemilahan yang berada di masing-masing dusun, dimana titik-titik tempat pemilhan ditentukan oleh Kepala Dusun. Pemilahan Sampah dilakukan di tempat pemilahan sementara yang berada di masing-masing dusun dengan memilah sampah Organik dan Unorganik. Dimana untuk sampah organik dikelola menjadi pupuk sementara sampah unorganik terutama limbah plastik akan dikelola menjadi bijih plastik. Bank Sampah adalah unit usaha yang berada dalam koordinasi BUMDes sehingga pemasaran hasil pemilahan sampah ornganik maupun unorganik akan dikoordinasikan melalui BUMDes.

\section{Daftar Referensi}

Koentjaraningrat. Pengantar Ilmu Antropologi. Jakarta: Aksara Baru, 1985.

Permendesa No. 2 tahun 2016 tentang Indeks Desa Membangun

Stiker, Gerry. Governance as theory: five propositions. International Social Science Journal, 1998.

Undang-Undang Nomor 6 tahun 2014 tentang Desa 